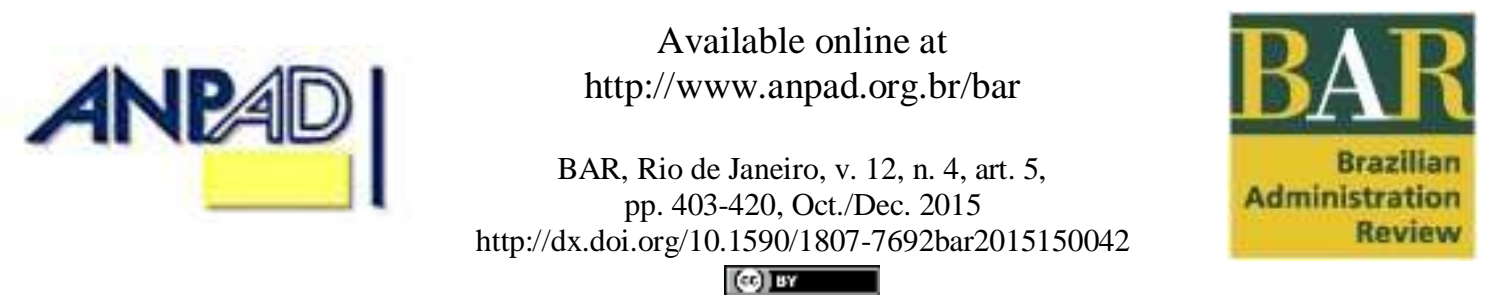

\title{
Diasporic and Transnational Internationalization: The Case of Brazilian Martial Arts
}

\author{
Angela da Rocha \\ Pontifícia Universidade Católica do Rio de Janeiro - PUC-Rio/IAG \\ Felipe Esteves \\ Pontifícia Universidade Católica do Rio de Janeiro - PUC-Rio/IAG \\ Renato Cotta de Mello \\ Universidade Federal do Rio de Janeiro - UFRJ/COPPEAD \\ Jorge Ferreira da Silva \\ Pontifícia Universidade Católica do Rio de Janeiro - PUC-Rio/IAG
}

Received 8 August 2015; received in revised form 20 November 2015; accepted 20 November 2015; published online 15 December 2015. 


\begin{abstract}
Brazilian diasporas overseas has received little academic interest. Nevertheless, estimates suggest that around three million Brazilians currently live in other countries. The present study looks at a specific type of diaspora: small entrepreneurs from the Brazilian martial arts sector. The study adopts the case study method of research. The unit of analysis is comprised by the martial arts (capoeira and Brazilian jiu-jitsu). Data analysis used secondary and primary data from interviews. Cross-case analysis searched for similarities and differences in the internationalization processes of the two martial arts, using several analytical devices, such as chronologies, timelines, matrices, and pattern matching analysis. Evidences suggest that the concept of diasporic internationalization fits better capoeira than Brazilian jiu-jitsu. However, Brazilian jiu-jitsu shows an initial combination of diasporic and transnational characteristics, but more recently became fully transnational. Brazilian jiu-jitsu became a truly global business, formally organized and professionally managed. Capoeira, however, is still seen as non-commercial and as the preservation and practice of an ancient art. Such ethos, combined with the origin of its members in lower economic classes and their restricted access to capital turns internationalization into an often less profitable activity.
\end{abstract}

Key words: diaspora; internationalization; martial arts; capoeira; Brazilian jiu-jitsu. 


\section{Introduction}

Scholars have looked at the role of diasporas from an ample set of perspectives: political, economic, social, historical, technological, and artistic, among many others. Most studies look at diasporas as an opportunity (e.g. supporting the diffusion of innovation, promoting FDI, or contributing to economic development), while others see them as a threat (e.g. internationalizing conflicts, separatism, or supporting terrorism).

Most of the literature on the role of diasporas comes from Sociology, Economics, Political Science, and International Relations. The International Business literature, in general, has given some attention to the role of diasporas, although the topic remains marginal. In the international entrepreneurship (IE) literature, few works, to our knowledge, have looked specifically at the role of diasporas in internationalization, a situation also reported by Nkongolo-Bakenda and Chrysostome (2013), who claim that diaspora research in the field of IE is still in its infancy. Lin (2010, p. 35) suggests that this topic has "gained recent attention among management scholars", and Álvarez (2015, p. 84) suggests a "need for further research and debate" on the subject. Nevertheless, a number of studies from other disciplines looked at the phenomenon of diasporic entrepreneurship (e.g. Rosenfeld, 2012; Saxenian, 2002; Wong \& Ng, 2002).

Brazil has been a major receptor of diasporic immigration throughout its history. Among the most often studied are the Japanese and the Syrian-Lebanese immigration during the 1930s; and the German and Italian immigration at the end of the 19th century and the first decades of the 20th century. In fact, around 4.5 million immigrants entered Brazil between 1870 and 1950 (Lesser, 1999).

In contrast, Brazilian diasporas overseas received little academic interest (Padilla, 2011). Nevertheless, estimates by the Brazilian Ministry of Foreign Affairs suggest that around three million Brazilians currently live in other countries (Ministério das Relações Exteriores, 2013). The present study looks at a very specific type of diaspora: small entrepreneurs from the Brazilian martial arts sector. Within this context, this study aimed at exploring two research questions: What elements of diasporic internationalization appear in the internationalization processes of Brazilian martial arts? What is the role of networking in diasporic internationalization processes?

\section{Literature Review}

\section{Diasporic internationalization}

Not all migrations are diasporic and not all diasporas are similar. Pries (2004) describes four types of international migrants: (a) the emigrant/immigrant, who has the intention of adopting the country of destination as his/her new homeland; (b) the return migrant, who intends to return to his homeland in a short period of time; (c) the diaspora migrant, who keeps the connection with the homeland, and avoids integration; and (d) the transmigrant, who is ambiguous about the nature and length of his/her migration. Butler (2001) identifies several types of diaspora, based on the motives behind their formation (e.g. captivity, exile, emigration etc.). According to this author, there is a consensus among scholars that three conditions are necessary to define a diaspora. First, people should be scattered in at least two hostlands. Second, there should be a continued relationship with the homeland (actual or idealized). Third, the people must display self-awareness of their group identity. Butler (2001) adds a fourth condition: that the process includes at least two generations. A diaspora can be understood, therefore, as a "social-spatial network" anchored in a symbolic capital "that enables it to reproduce and overcome the often considerable - obstacle of distance separating its communities" (Bruneau, 2010, p. 36).

Several authors make a distinction between diasporic internationalization and transnational internationalization. However, there is no consensus in the literature on the meanings of these terms. 
For example, Pries (2004) conceptualizes diasporic internationalization with reference to a common homeland that unites the members of a group located in different geographic spaces. In contrast, transnationalization is defined by "pluri-local and transnational social relations, networks and practices ... which simultaneously exist above and beyond the social contexts of national societies" (p. 28). Faist (2010, p. 11) suggests that the term "transnationalism" refers to the "practices of migrants engaged in various activities", including "small-scale entrepreneurship of migrants across borders". In this study, we adopt the conceptualization proposed by Pries (2004).

\section{Network theory and diasporic internationalization}

Network theory in the context of internationalization processes moved the focus from the individual firm, as a lonely player in the international arena, to a multi-firm network (Bonaccorsi, 1992; Dana \& Wright, 2004). Yet, as pointed out by Hintu, Forsman and Kock (2004, p. 719), this literature has largely ignored "natural persons" as key elements in social networks. In the case of diasporas, personal networks tend to be at least as important as firm-based networks.

Networks are in the essence of the concept of diasporas. Diasporas keep network ties with the homeland and use the network to support new members. The link between diasporic entrepreneurs and domestic firms is well established. For example, Nanda and Khanna (2010) found that Indian entrepreneurs with international experience tend to rely more on diasporic networks to get commercial deals and financing than those that did not, and Rosenberg (2012) shows how entrepreneurs in Lebanon organize their supply chain with members of the Lebanese diaspora. Family network also seems to have a role among certain diasporic groups. For example, Wong and Ng (2002) mention the connections between Chinese entrepreneurs in Vancouver and other of their family's businesses in different geographic locations (e.g. Hong Kong, China, and Taiwan). Tung and Chung (2010) show that Chinese decision-makers in Australian firms have a higher probability of choosing a higher-commitment entry mode in China.

Yeung (2004) departed from the sociological literature on Chinese overseas entrepreneurship to adopt a network approach to explain the geographic spreading of these firms across different regions and countries. He found that Hong Kong entrepreneurs did not rely only in family networks in their commercial ventures in Southeast Asia, but in several different types of network. Accordingly, he proposed that three types of network ties were relevant to explain the phenomenon: intra-firm (parentsubsidiary relations), inter-firm, and extra-firm (firm and local institutions). He also posited that networks changed dynamically, and new forms of Chinese networks emerged. An issue that deserves further attention is the role of the internet in supporting diasporic internationalization. The internet has given diasporic communities the ability to communicate among them and with the homeland, and to reinforce their symbolic common ties (Kissau \& Hunger, 2010).

In this study, we adopt the term diasporic entrepreneurial network to refer to migrant entrepreneurs who remain connected to homeland-based networks as their primary source of group identity and business legitimacy. In opposition, we use the term transnational entrepreneurial network to refer to the establishment of a business network overseas that does not depend on its identity and legitimacy on the ties (real or imaginary) with the homeland.

\section{Methodology}

The study adopts the case study method of research. The use of case studies is still limited in the International Business literature (Pauwels \& Matthyssens, 2004), although they have been used more often in the field of International Entrepreneurship. The choice of case studies is consistent with the subject matter - diasporic internationalization - whose understanding the researchers intend to advance (Ghauri, 2004). The subject matter has been researched insufficiently (Nkongolo-Bakenda \& Chrysostome, 2013), thus suggesting a need for more qualitative research. In addition, we adopt a 
longitudinal (retrospective) design to understand how the phenomenon under investigation has evolved (Blazejewski, 2011). Finally, the case method seems more appropriate when the unit of analysis is not a firm but an industry.

The unit of analysis is comprised by the martial arts (capoeira and Brazilian jiu-jitsu). These cases are largely outliers or "black swans" (Aharoni, 2011, p. 47), since no martial arts have their origins outside Asia, and none from a country without tradition in the battlefield, such as Brazil. Therefore, the fact of these martial arts have been internationalized, despite their unusual national origin, suggests that these cases deserve to be objects of study. Data came mainly from secondary sources - necessary to acquire a historical perspective of the internationalization process of Brazilian martial arts complemented by in-depth interviews with three experts in martial arts (one former jiu-jitsu champion, one capoeira master, and a black belt who established a jiu-jitsu academy in Asia). None of the interviewees had previous international experience. The interviews were carried out in 2014 with a semistructured protocol. The use of a large variety of secondary sources and personal interviews allowed for triangulation.

Cross-case analysis searched for similarities and differences in the internationalization processes of the two martial arts. We used several devices to compare the results that emerged from the two cases, such as chronologies, timelines, matrices, and pattern-matching analysis (Ghauri, 2004). The results were then contrasted to identify emerging patterns, and compared to the literature.

\section{The Cases}

\section{Case 1: Capoeira}

Capoeira is a cultural expression of African - Brazilian origin that combines martial art, sport, ritual, play, dance, and music. Controversy surrounds capoeira history. Although most researchers find its origins in martial practices of Central African warriors, some authors also recognize the influence of Brazilian aboriginal dances (Assunção, 2005; Thompson-Chvaicer, 2008). In spite of this, there is undisputable historical evidence that African slaves developed that art. Several myths were developed around the capoeira and they were seen as part of an idealized heroic period of the fight against slaveowners (Vieira \& Assunção, 1998). Banned for several decades, only in 1937 the practice of capoeira was again legally permitted. Ironically, it would then become a symbol of national identity (Assunção, 2005). From the 1960s on, capoeira spread throughout Brazil, leading to several initiatives to regulate and institutionalize the martial art, including the creation of a Brazilian Federation of Capoeira and its inclusion as an official Brazilian sport. A consequence of the institutionalization of the capoeira was the adoption of several practices typical of other martial arts: white uniforms, barefoot, color cords to indicate the level of the practitioner, ritual greetings before and after the fight, and a martial posture (Frigério, 1989).

Capoeiristas (practitioners of capoeira) are organized in groups. Master capoeiristas lead these groups, some of which developed into schools, each having its own distinctive characteristics (e.g. group name, location, uniform, symbols). These organizations can be formal or informal, profit or nonprofit. An original group of capoeira can start new groups in other locations, which remain affiliated to the original group. The largest groups can have affiliated groups in other cities of Brazil and in other countries. The current form of organization of capoeira groups has some elements of franchising and licensing. For example, if a master graduated by a capoeira group decides to open his own school, he adopts the membership of the original group upon payment of a financial provision based on the number of students he is able to attract. In addition to license for use of the name, the mother school offers several types of products (such as clothing, shoes, musical instruments, reading material, CDs and DVDs, etc.), which are sold to students. Practitioners do not discuss or question the commercial aspect of the activity; the capoeira masters cultivate an image of standing above material matters (Lussac \& Tubino, 2009). Capoeira groups in Brazil or abroad also tend to be associated to a National Federation 
or to the International Federation of Capoeira (established in Oviedo, Spain), abiding to their norms and paying fees.

In the 1960s, the Brazilian government made a special effort to promote capoeira abroad. In the early 1970s, master capoeiristas established the first schools of capoeira in the United States (New York and California) and several others in European countries. In the 1980s, a period of economic crisis in Brazil (known as the lost decade), many master capoeiristas migrated to the U.S. and Europe, in search of opportunities (Wulfhorst \& Vianna, 2012). The increasing appearance of capoeira in the mass media also helped its diffusion in the 1990s. Movies, videogames, advertising, books, and music videos portrayed or mentioned capoeira. In addition, the use of capoeira in the advertising of multinational companies helped to promote the martial art abroad (Delamont \& Stephens, 2008).

According to the International Federation of Capoeira, there are eight million capoeira practitioners in the world, of which six million are in Brazil and the other two million (25\%) are spread over 150 countries. Interestingly, however, capoeira remains a martial art of the diaspora, because of certain characteristics. First, the martial art increased its global reach through the immigration of Brazilian capoeiristas, who control the teaching of capoeira overseas. Second, the language of capoeira abroad is still the Portuguese; students have to learn many terms and songs in Portuguese. Third, instructors present the martial art as an authentic expression of the Brazilian culture (Delamont \& Stephens, 2008).

The typical capoeiristas overseas are Brazilian immigrants (often illegal) from lower-income families, who moved to another country in search of opportunities. Joseph (2008) claims that many capoeiristas - being dark-skinned and coming from the lower social classes - found migration to more developed countries a very attractive alternative to their low social status and underpaid situation in Brazil. They start their activities in precarious conditions, often supplementing income with underemployment. Falcão (2008) claims that locals do not perceive these professionals negatively because they do not compete for a local job. Lacking funds to start their business, these diasporic international entrepreneurs often strive to survive and make several attempts to start their own business until they finally succeed. A major barrier to the success of these entrepreneurial efforts is the lack of formal education in general, and the lack of management education in particular. Many entrepreneurs lack basic knowledge of finance and marketing, hindering their schools' development.

Wulfhorst and Vianna (2012, p. 87) contrast the closed network tradition of capoeira with its global presence: "Capoeira is also essentially defined by a sense of a close-knit community of participants (particularly within a specific group), as well as by a broader global identity (since practitioners belong to a globally disseminated art form)". A negative consequence of this ambivalence to the internationalization of capoeira is an excessive importance given to the specific group and network, to the detriment of a more globalized perspective. "This organizational pattern reinforces closed approaches to networks and group cohesion, consequently creating a strong sense of shared identity within, but not necessarily across, Capoeira groups" (Wulfhorst \& Vianna, 2012, p. 89). The authors argue that the emphasis on the exotic and authentic nature of capoeira is a form used by capoeiristas abroad to set a unique positioning for capoeira. As a result, there is some prejudice against non-Brazilian instructors, based on claims that they do not represent the authentic capoeira.

Capoeira groups have websites that promote their art. An ethnographic study by Joseph (2008) provides the following description of a website of a Canadian capoeira group:

The GC Web site is central to the group marketing strategy and features images and videos of muscular dark-skinned men (the majority of whom are, in fact, Jamaican-Canadians) playing capoeira or leading classes and rodas for a multiracial group of male and female students. The male leaders act as metonyms for the originators of capoeira, Afro-Brazilian slaves, described in the accompanying text. The GC Web site offers narratives and imagery that recount the history of capoeira in the context of slavery in Brazil; descriptions of various styles of Afro-Brazilian dances, music, and religious practices; detailed stories of the mestres' childhoods in Brazil; and documentation of the teachers' spectacular movements in various rodas and travels to 
international capoeira events. These features distinguish GC from other local, inauthentic capoeira groups by offering proof of its legitimate links to African ancestry, Brazilian nationality, and broader capoeira communities (Joseph, 2008, p. 506).

The use of social media has substantially increased the contacts between groups and practitioners in different countries. These contacts in the virtual space may help to overcome the limitations imposed by closed groups and to expand the network of capoeiristas beyond their own groups, thus contributing to reinforce the global character of the art (Wulfhorst \& Vianna, 2012). In addition, the increasing number of adepts of capoeira in different countries is changing the diasporic nature of capoeira (Joseph, 2008). This is caused by the growing participation of foreign masters and practitioners who are neither Brazilian, nor of African descent.

Every capoeira school or group of any relevance has affiliated groups abroad. For example, one large capoeira group declared to have more than 60 affiliated groups in different countries. The internationalization process started in 1984, by chance:

"The Master was invited by a friend, who has lived in the United States for almost 40 years. He is a good friend of the Master. When his work began to grow, he invited the Master to an event there. And the Master went with three of his students. And one stayed there. He started a group." (personal interview, 7/8/2014).

Table 1 presents the number of affiliates of leading capoeira groups and the number of countries (including Brazil) where they have a presence.

Table 1

Size and Scope of Selected Internationalized Capoeira Groups

\begin{tabular}{lccc}
\hline Name & Year of Foundation & No. of Affiliates & No. of Countries \\
\hline Abadá-Capoeira & 1988 & 338 & 48 \\
Filhos de Bimba Escola de Capoeira & 1986 & 18 & 10 \\
Grupo Capoeira Brasil & 1989 & 82 & 34 \\
Grupo Cordão de Ouro & 1967 & 162 & 34 \\
Grupo Ginga Capoeira Regional & 1972 & 92 & 22 \\
Grupo Senzala & 1965 & 116 & 40 \\
\hline
\end{tabular}

Note. Source: websites of the groups and affiliates.

Group members value their connections with a major capoeira school in Brazil. In fact, fees paid by foreign capoeira groups to the original Brazilian group can represent as much as $75 \%$ of a Brazilian capoeira school's income. Internationalization poses, however, several threats to capoeira schools, and requires at least investments in protecting the brand name. In addition, the Brazilian schools exert some sort of loose control over its affiliates. The master, or his top disciples, should travel regularly to each foreign affiliate, to give special classes and demonstrations, and to ensure that the rules are effectively applied (e.g. the compliance to the principles of the association, the correct use of gradation cords, etc.). He receives extra payment for each trip. Formal mechanisms of control are however absent.

The idea of a family is behind the constitution of a capoeira network. The relationship between the Master and his former students is one of respect and trust:

"It is like a family. The Master has the name [of the network association] and his students carry the name. These students have had other students, who already had other students. For example, I've been here for 19 years, the master is like a father. Two thirds of my life, I've spent here. And I can tell him: 'Master, one of my students from Colombia wish to enter the group...' And he will accept him." (personal interview, 7/8/2014). 
It is a matter of honor and a crucial responsibility of the foreign instructor to abide to the rules of the Brazilian Master, as reported in an ethnography of a capoeira group in Canada (Hedegard, 2012):

The ultimate authority resided with the Brazilian master, always referred to as 'our master.' ... The Brazilian master organized workshops several times per year, at which attendance was required for all but beginners. Through years of practice, advanced students attend many of these events, learning how to reproduce this Brazilian's vision of capoeira. [The instructor] felt pressure from the larger Brazilian-run organization to maintain these traditions to legitimate himself and his group, and he evaluated his advanced students' commitment to their Brazilian master and lectured them about their responsibilities (pp. 519-520).

In fact, if an instructor at a foreign location fails to keep the traditions and rules of the original group, he may be banned from the network:

"I've been in events abroad in which no one was wearing the graduation. And I said to the guy: 'What's going on here?' And he [said]: 'Well, we don't like to change the graduation too often...' And I said; Look, son... If you use the logo, you have to do it our way.' He ended by leaving the group. Exactly because of that." (personal interview, 7/8/2014).

In addition, Brazilian schools organize events in Brazil to attract diasporic members and foreign practitioners, and therefore strengthen the ties among network members. Foreign capoeiristas also frequently visit Brazil in order to attend classes or workshops and to get an authentic feeling for capoeira (Green \& Svinth, 2010). Griffith $(2013$, p. 2) suggests that these "apprenticeship pilgrims" search for legitimacy by travelling to Brazil and by having classes with highly renowned masters:

One American pilgrim ... said visiting Bahia is valuable for moving to the next level within capoeira because 'it is such an odd blend of things, and you have to see the place that would create this'. He also felt it was important to visit the places mentioned in some of the capoeira songs.

\section{Case 2: Brazilian Jiu-Jitsu}

Brazilian jiu-jitsu (also known as Gracie jiu-jitsu) is a martial art developed by the Gracie family in the first decades of the 20th century in Brazil, based on the Japanese jiu-jitsu. The Japanese master Mitsuyo Maeda brought jiu-jitsu to Brazil in 1915. He had among his students a young man, Carlos Gracie, who became a competent fighter. Carlos then taught his younger brothers. He established a jiujitsu academy in Rio de Janeiro in 1925 (Walder, 2008). Carlos and his younger brother Helio would then become the founding fathers of the Brazilian style of jiu-jitsu. They adapted the original martial art in order to reduce the amount of effort required from the fighter and to increase his/her effectiveness, making it "more suitable for men and women of all ages and sizes" (Nelson, 2013, p. 34).

The new style of jiu-jitsu spread in Brazil, after Helio Gracie - at a very young age, short, weighting only 60 kilos, and lacking physical strength - defeated the Brazilian champion of boxing, as well as one of the most renowned capoeira masters. He later also defeated the world champion of sumo, and the Japanese vice-champion of jiu-jitsu. More than 40 members of the Gracie family dedicated their lives to the diffusion of the martial art.

In the 1970s, members of the Gracie family settled in the U.S. to teach the Brazilian jiu-jitsu. However, the scope of these initiatives was limited, reaching only the small circle of practitioners. In the 1980s and early 1990s, members of the Gracie family also went to other cities in the U.S. and in Europe, with the mission of promoting the Brazilian jiu-jitsu style and of starting local academies. Sensational victories of Gracie family members consolidated Brazilian jiu-jitsu in the U.S. and in other countries (Nelson, 2013).

In 1989, Rorion Gracie founded the Gracie Academy in the U.S., and later started a TV program called Ultimate Fighting Championship (UFC). His purpose was to demonstrate the superiority of Brazilian jiu-jitsu over all other forms of combat. Besides promoting the diffusion of the art, he intended to show that it was the best means of overcoming a stronger opponent. Royce Gracie became the first 
UFC champion (Green \& Svinth, 2010). He later sold the TV program to avoid financial losses. Nevertheless, the UFC was crucial to the diffusion of Brazilian jiu-jitsu in the U.S. Later, the MMA (for Mixed Martial Arts) has also played a major role in the diffusion process; the growing interest in mixed forms of martial arts has helped to promote the Brazilian jiu-jitsu worldwide. As noted by Cannon (2012) and Nelson (2013), the diffusion of Brazilian jiu-jitsu is mainly due to its superiority in arenas that allowed the confrontation between fighters of any martial art.

Hollywood movies also helped to give visibility to the Brazilian style. In addition, the adoption of jiu-jitsu training by police forces and armies in the U.S. and several Arab countries (e.g. Jordan, Unites Arab Emirates) helped the Brazilian style to attain legitimacy.

Because of these factors, Brazilian jiu-jitsu has become the most widespread form of jiu-jitsu in the world, far surpassing the original style. The international federation representing the sport is the International Brazilian Jiu-Jitsu Federation (IBJJF), with offices in the United States (Irvine, California) and Brazil (Rio de Janeiro), and 332 members. Table 2 presents the main countries of member academies of IBJJF. The U.S. is by far the country with the largest number of members (41\%), followed by Germany, Portugal, France and Japan (Brazil is not included). This large concentration of academies in the U.S. may be due also to the fact that the IBJJF is located only in the U.S. (besides Brazil). In addition, it should be noted that smaller academies are often not members of IBJJF, and that other associations also congregate Brazilian Jiu-Jitsu academies.

Table 2

\section{Location of Headquarters of IBJJF Member Academies (Main Foreign Countries)}

\begin{tabular}{lclclc}
\hline Country & No. & Country & No. & Country & No. \\
\hline 1. U.S. & 136 & 6. Canada & 15 & 11. U.K. & 7 \\
2. Germany & 23 & 7. Spain & 15 & 12. Greece & 5 \\
3. Portugal & 17 & 8. Australia & 10 & 13. Finland & 4 \\
4. France & 16 & 9. Italy & 9 & 14. Mexico & 4 \\
5. Japan & 16 & 10. Switzerland & 8 & 15. UAE & 4 \\
\hline
\end{tabular}

Note. Source: website of International Brazilian Jiu-Jitsu Federation. (2015). 2015 registered. Retrieved from http://ibjjf.org/registered/

The internationalization of jiu-jitsu, therefore, started mainly as an initiative of the prolific Gracie family, but later other entrepreneurs also opened academies in several countries. Although the first group of international entrepreneurs tended to belong to the middle classes, this situation has changed somewhat with the international diffusion of the martial art. Athletes coming from poorer families that attained success in national and international competitions have recently found their path to internationalization.

The most common form of internationalization occurs when a successful academy in Brazil, usually led by a renowned black belt, opens a branch in another country. The country of choice depends on the identification of an opportunity, or even a foreign demand (for example, from large fitness centers or universities abroad). The new branch can be formally or informally associated with the original center. Financial compensation for the use of the name between the foreign affiliate and the Brazilian academy may take several forms. In some cases, there is a fixed fee paid to the Brazilian headquarters; in other cases the Brazilian academy gets a percentage over profits. In other cases, the affiliate only pays for regular seminars and workshops given by the Brazilian academy. Sometimes, there is no compensation, as reported in a study:

The willingness to help those in need was the driving force of the internationalization project.... He received several proposals of friends abroad to use the name of his academy. [As a result,] he 
celebrated informal agreements, which did not provide any financial compensation. $\mathrm{He}$... intended to formalize the relationship with the representatives, hoping for better results in international championships for the representatives themselves (Matta, Dib, \& Mello, 2013, p. 8).

The same study reports the case of a black belt who went with three disciples to Japan to make contacts in order to start an affiliate there:

Despite ... the total ignorance of Japanese culture and habits, these aspects were no longer relevant, as the determining factor was the network they belonged to, which was a guarantee for them in this process... [He] and his international partner were aware of their importance to each other... (Matta et al., 2013, p. 9).

In some cases, however, a black belt opens his/her own academy abroad without any association with a Brazilian jiu-jitsu academy. For example, a Brazilian entrepreneur moved to Malaysia to start a jiu-jitsu academy independently. Although the first attempts were not very successful, he ended by starting an academy with a small group of students. In his efforts to increase the number of students, he decided to start a blog:

"I was too small [to be viable]. I kept asking myself 'How am I going to attract more people to train with me?' And I had the idea of having a blog. And I started to receive emails: 'I would like to know more about Brazilian jiu-jitsu, I always wanted to know...' And one day a guy appeared with three of his students to test me. I trained with them and he liked it. Later he passed some of his students to me. And I moved from 15 to 30 students. Then I needed more space. But I could not anymore work with all the students. I started to use my best students to help me with the classes." (personal interview, 6/6/2014).

There is substantial international activity among jiu-jitsu practitioners. Instructors travel to different places in the world two to three times a year, to attend seminars and jiu-jitsu training camps. The seminars typically last only one day; the instructors are renowned black belts. Jiu-jitsu training camps last longer (from seven to fifteen days). Participants pay for a package that includes classes, training, uniforms, meals, and stay on the training ground. A team of instructors of the academy responsible for organizing the event teaches the classes. This is an opportunity for instructors and practitioners from different parts of the world to interact and share experiences. Although some of these activities target only affiliated academies abroad, a number of them are open to any practitioner from any country and academy. In international championships and tournaments, each network, independently of the location of the academy, presents itself as a single unit, under the same brand name. Therefore, positive results can help to increase the reputation of the network as a whole.

Table 3 summarizes the main characteristics of the internationalization processes of the two martial arts and the characteristics of the entrepreneurs.

Table 3

Characteristics of the Brazilian Martial Arts Internationalization

\begin{tabular}{lll}
\hline Characteristics & Capoeira & Brazilian Jiu-Jitsu \\
\hline Characteristics of the Internationalization Process & \\
\hline First schools abroad & 1970s & 1970s \\
First countries/ regions & U.S. and Western Europe & U.S (1970s and 1980s) \\
& & Western Europe (1980s) \\
No. of countries (2014) & Approximately 150 & Approximately 80 \\
Main markets & U.S./Japan/U.K./Spain/Germany & U.S./ Germany /Portugal \\
& & /France/Japan/Canada \\
No. practitioners abroad (2014) & Around 2 million & Not available \\
\hline
\end{tabular}


Table 3 (continued)

\begin{tabular}{|c|c|c|}
\hline Characteristics & Capoeira & Brazilian Jiu-Jitsu \\
\hline \multirow[t]{3}{*}{ Instruments of diffusion } & $\begin{array}{l}\text { Formation of capoeira groups } \\
\text { abroad }\end{array}$ & $\begin{array}{l}\text { Victories in World Championships } \\
\text { by the Gracies }\end{array}$ \\
\hline & $\begin{array}{l}\text { Movies, ads, videogames, books, } \\
\text { music videos }\end{array}$ & $\begin{array}{l}\text { Opening of academies abroad } \\
\text { Movies, UFC, MMA }\end{array}$ \\
\hline & Internet and social media & $\begin{array}{l}\text { Adoption by military and police } \\
\text { forces abroad }\end{array}$ \\
\hline International positioning & $\begin{array}{l}\text { An exotic and authentic African- } \\
\text { Brazilian martial art }\end{array}$ & $\begin{array}{l}\text { The Brazilian version of an ancient } \\
\text { martial art }\end{array}$ \\
\hline Symbolic claims & $\begin{array}{l}\text { Uniqueness, authenticity, African } \\
\text { ancestry, fight for freedom }\end{array}$ & A superior martial art \\
\hline International language & Portuguese & English \\
\hline \multicolumn{3}{|c|}{ Characteristics of the Entrepreneur } \\
\hline Class & Lower classes & Middle classes \\
\hline Race & Dominantly African-Brazilian & Initially Caucasian; later all races \\
\hline Gender & Male & Male \\
\hline Education & $\begin{array}{l}\text { Less educated; lack of English- } \\
\text { speaking skills }\end{array}$ & $\begin{array}{l}\text { Mostly educated; English-speaking } \\
\text { skills }\end{array}$ \\
\hline Motive to migrate & Search for better opportunities & Diffusion of the martial art \\
\hline Initial Funding & Wages earned in foreign countries & Family funding \\
\hline
\end{tabular}

The internationalization process of both martial arts happened within the same period, as depicted in Figure 1. In spite of that, the internationalization of capoeira reached a broader scope (in terms of number of countries).

\begin{tabular}{|c|c|c|c|}
\hline $\begin{array}{l}\text { First schools opened } \\
\text { in the U.S. and } \\
\text { Western Europe }\end{array}$ & $\begin{array}{l}\text { Massive immigration } \\
\text { of capoeiristas to the } \\
\text { US and Western } \\
\text { Europe }\end{array}$ & $\begin{array}{l}\text { Diffusion by the mass } \\
\text { media (Hollywood } \\
\text { movies, music videos } \\
\text { etc.) }\end{array}$ & $\begin{array}{l}\text { Growing number of } \\
\text { countries with capoeira } \\
\text { groups ( } 150 \text { in 2014) }\end{array}$ \\
\hline $1970 \mathrm{~s}$ & $1980 \mathrm{~s}$ & $1990 \mathrm{~s}$ & 2000 s on \\
\hline \multicolumn{4}{|c|}{ a. Timeline of the internationalization of Capoeira } \\
\hline $\begin{array}{l}\text { First classes in the } \\
\text { U.S. by Gracie } \\
\text { family members }\end{array}$ & $\begin{array}{l}\text { Several Gracies mov } \\
\text { to the U.S. to teach I } \\
1989 \text { - Gracie } \\
\text { Academy in Califorr }\end{array}$ & $\begin{array}{ll}\text { red } & 1993-\text { UFC } \\
\text { BJJ } & 1998 \text { - 1st Gracie } \\
& \text { academy in Europe } \\
\text { aia } & \text { (Spain) }\end{array}$ & $\begin{array}{l}\text { BJJ adopted by several } \\
\text { police forces and armies } \\
\text { in Arab countrie } \\
\text { Growth of MMC } \\
\text { around } 80 \text { countries }\end{array}$ \\
\hline $1970 \mathrm{~s}$ & $1980 \mathrm{~s}$ & $1990 \mathrm{~s}$ & 2000 s on \\
\hline
\end{tabular}

Figure 1. Timeline of the Two Internationalization Processes

Source: Ministério das Relações Exteriores. (2013). Perfil da diáspora brasileira: estimativas. Retrieved on 19 January, 2015, from http://www.brasileirosnomundo.itamaraty.gov.br/a-comunidade/estimativas-populacionais-dascomunidades/estimativas-populacionais-das-comunidades-brasileiras-no-mundo-2013/estimativas-2013-site.jpg 


\section{Discussion}

The discussion covers two issues: (a) the nature of the internationalization process; and (b) the process by which networks are established and developed in these martial arts.

\section{The nature of the internationalization process}

The evidence collected in this study suggests that the concept of diasporic internationalization (Pries, 2004) fits better capoeira than Brazilian jiu-jitsu. However, the internationalization process of Brazilian jiu-jitsu shows an initial combination of diasporic and transnational characteristics, but more recently became fully transnational.

The diasporic character of capoeira's internationalization is undisputable. There is plenty of evidence that capoeira groups outside Brazil make a substantial effort to remain connected to their roots; not only to the country, but also to their specific original Brazilian group. In addition, one of the ways by which capoeira groups keep their links with the homeland is by rejecting the leadership of nonBrazilian master capoeiristas. The connection to Brazil, to a specific capoeira group and to a renowned Master is very important because authenticity is a key marketing claim of foreign schools. Capoeira groups differentiate themselves from non-authentic groups by cultivating these links and tracing their lineage to one of the great masters.

In contrast, the Brazilian nationality is not a relevant element of group identity in the case of Brazilian jiu-jitsu. Group cohesion comes from a shared identity as Brazilian jiu-jitsu practitioners, built around the martial art itself. Three reasons may explain the difference. First, jiu-jitsu is not originally a Brazilian martial art; rather, Brazilians adopted, modified, and improved the art. Therefore, it never carried a strong sense of nationality, as capoeira did. Second, the art spread due to a single-family diaspora. It is an extraordinary accomplishment that only one family (later a clan) - the Gracies - is behind the creation and initial international expansion of this new style of an old Asian martial art. To our knowledge, no other sport or martial art is so highly indebted to one family. The family diaspora aimed intentionally at developing the new style in other countries. Nevertheless, and despite the large size of the Gracie family, the martial art could not have expanded globally if it had to remain within the scope of the family. Inevitably, non-family members had to enter the business, and it did not seem to matter if they were or not Brazilians. Finally, the real international arena for the Brazilian jiu-jitsu became the United States, not Brazil, further supporting its transnational character.

Other differential characteristics in each internationalization process refer to the type of entrepreneur. The typical capoeira entrepreneur was, until recently, an individual of African-Brazilian descent from the lower or the lower-middle classes in Brazil, who migrated in search of new opportunities, a typical case of diasporic motivation (Butler, 2001). To some extent, it is much more difficult for a white capoeirista to establish a school of capoeira abroad, given the emphasis on the African tradition and the idealized past of fight against slavery. The positioning of the art is not conducive to have white-skinned masters heading the internationalization. This is an additional explanation for the prejudice against foreign capoeiristas.

In contrast, the Brazilian jiu-jitsu entrepreneur tended to be white-skinned, more educated, and to belong to the middle class. The original migrants were members of the Gracie family and had a sense of mission - to spread the martial art abroad. This is not a classic motivation for the diaspora (Butler, 2001). Yet, despite the family consensus on sending members to other countries to disseminate the Brazilian style - which had proved to be superior in combat - it is possible that the search for new opportunities was a secondary goal for younger brothers and to the second and third generation of the Gracies since the family grew to become a clan. With the family support, it was of course much easier for them to establish themselves in other countries where the Gracies had already established a name. More recently, many other black belts without a connection to the family have followed the same path, but their profile tended to be to some extent similar. One reason might be that, while the Portuguese 
remained the dominant language of capoeira throughout the world, Brazilian jiu-jitsu became an English-speaking art, requiring some level of proficiency, and therefore the attainment of a certain level of education, not easily available to lower class members in Brazil. Only recently, the upper-class status of jiu-jitsu entrepreneurs from Brazil appears to be changing, with successful practitioners from the lower classes moving up the social hierarchy.

The combination of these characteristics resulted in the adoption of a business approach in the case of Brazilian jiu-jitsu. It became a truly global business, formally organized. Capoeira, however, is still seen as non-commercial and as the preservation and practice of an ancient art. Such ethos, combined with the origin of its members in lower economic classes and their restricted access to capital, turns internationalization into an often less profitable business, both for the Brazilian organization and for its affiliates across the world.

As a result of these characteristics, the scope and speed of internationalization of the two martial arts tend to differ. Capoeira has spread over a larger number of countries than Brazilian jiu-jitsu. In fact, at this point a capoeira group can be found in the most improbable places, those with the largest psychic distance to Brazil, with low-income populations, and in some of the most remote areas of the planet. Brazilian jiu-jitsu, however, tends to concentrate in regions of middle to high income.

\section{The role of networks in the internationalization process}

Because jiu-jitsu practitioners share their interest in the martial art in spite of their specific lineage, they form a more global group. Capoeira practitioners, however, are loyal to their specific group, rather than to the martial art. As a result, one expects to find larger networks among jiu-jitsu practitioners, which are not limited to their affiliation to a Brazilian group.

The formation of networks in the internationalization of Brazilian martial arts is remarkably interesting. Especially in the case of capoeira, there are networks of natural persons rather than networks of organizations. Capoeira organizations are often only a way to facilitate and legalize the relationship between the groups in different countries. The organization serves to manage the flow of products, services and fees, that is, the commercial side of capoeira. It is also important because it carries the brand name of the group. However, the ties that really matter are those among the Master and his students, and the students of his students. In the case of Brazilian jiu-jitsu, although the relationships are also personal, the role of the academies appears to be comparatively more important. Nevertheless, practitioners often trace their genealogy to one of the Gracie champions, based on who learned with whom. This ancestry is therefore important to practitioners in both martial arts, and explains to some extent the nature of the networks in their internationalization processes.

The capoeira network, compared to the jiu-jitsu network, is more close-knitted as the ties among members are stronger, and mostly based on respect and trust. In contrast, for Brazilian jiu-jitsu members it seems that the value of the organization's reputation and of a brand name counts more than for the capoeiristas; jiu-jitsu networks tend to be more business-oriented and more global. Summing up, the type of network in the capoeira internationalization process is predominantly a diasporic entrepreneurial network, while in the case of Brazilian jiu-jitsu it is at this point more of a transnational entrepreneurial network.

The internet and the social media provide a valuable opportunity for diasporic capoeira groups to connect to their original group and to strengthen their network ties. It is a way to build virtual bridges between foreign-established groups and the original Brazilian capoeira group. In fact, capoeira groups overseas use the internet as a way to enhance their diasporic identities. The importance of virtual connections is probably linked to the limited wealth accumulated by capoeira masters abroad. In contrast, the internet is much less important in the case of Brazilian jiu-jitsu. Because of its business approach, jiu-jitsu academies seem to use the internet as any other business organization does.

The nature of the ties in these networks can also be examined using Yeung's (2004) typology. Capoeira groups preserve mainly their intra-group ties, which extend across borders to our master. 
They tend to avoid inter-group ties because it threatens their sense of identity and their loyalty to the original master and group in Brazil. Such behavior is not uncommon and has been reported also in connection with Japanese groups (Nakane, 1970). Brazilian jiu-jitsu groups, however, develop intragroup (within their network), inter-group (with other networks), and extra-group ties (with other sports and external organizations, such as the MMA). The reason for this openness can be traced to the positioning of Brazilian jiu-jitsu, since its inception, as superior to other forms of combat. Therefore, its practitioners had to confront the practitioners of other martial arts and to interact continuously with them.

Table 4 summarizes this discussion.

Table 4

Nature of Networks in the Martial Arts

\begin{tabular}{lll}
\hline Nature of the network & Capoeira & Brazilian Jiu-Jitsu \\
\hline Type & Diasporic entrepreneurial network & Transnational entrepreneurial network \\
Ethos & $\begin{array}{l}\text { Non commercial } \\
\text { Strong sense of nationality }\end{array}$ & $\begin{array}{l}\text { Business-like } \\
\text { Global }\end{array}$ \\
Speed & Slower & Faster \\
$\begin{array}{l}\text { Economic performance of the } \\
\text { network }\end{array}$ & Lower & Higher \\
Links & Among natural persons & Among natural persons and among \\
& Predominantly intra-group & $\begin{array}{l}\text { organizations } \\
\text { Intra group, inter-group and extra- } \\
\text { group }\end{array}$ \\
\hline
\end{tabular}

\section{Final Considerations}

This study explored a research area that international business and international entrepreneurship scholars have largely ignored: diasporic internationalization processes. We looked specifically at two cases of Brazilian martial arts that present at least some characteristics of diasporic internationalization, and contrasted the two cases in order to extract insights on how the process evolves.

The paper contributes to the IB literature in several regards. First, it contributes to the understanding of how Brazilian migrants in the martial arts use their networks to reaffirm their intragroup, inter-group, or extra-group ties, as well as their bonds with the homeland. Although previous research has consistently shown the importance of networks in diasporic internationalization, this study's results suggest that the nature and strength of ties can differ depending on the contextual factors of each activity.

Second, although reaffirming the role of personal (in opposition to firm) networks in diasporic and transnational internationalization, the study shows that these networks are mainly built around a very specific group of members, who share a common identity. In the case of Brazilian jiu-jitsu, the network goes beyond group members to include specific organizations created around the martial art.

From this perspective, even within the martial arts sector, the two activities here examined present a different way of organizing and using networks, although they could look at first glance quite similar. Yet, the two cases reaffirm the importance of networks to the internationalization process of migrant entrepreneurs in martial arts, in agreement with the extant literature and with the revised Uppsala model (Johanson \& Vahlne, 2009). 
Third, it addresses the issue of entrepreneurial characteristics in terms of social class. In contrast with the extant literature, that suggests that migrant entrepreneurs are mainly well-educated and with a technical background (Kenney, Breznitz, \& Murphree, 2013; Saxenian, 2002), this study shows that migrant entrepreneurs may come from different social classes, and may not be well-educated, or have been exposed to new technologies. It is interesting to note that Álvarez (2015) also points out to a different profile among Colombian migrants living in the U.S.

Fourth, it sheds light on a specific type of migrant entrepreneurial activity, related to martial arts. To our knowledge, the internationalization of martial arts has been rarely studied in the area of International Business, although it has received attention in other fields. Both martial arts seem to be able to continue their international expansion, and should therefore be an interesting area for more scholarly research in International Business.

The work presents several limitations. First, most of our research uses secondary data, due to the difficulty of gathering historical information using primary data. Nevertheless, the use of secondary data entails an intrinsic problem, because the researcher has no control over the data collection process. To overcome these limitations we were careful in triangulating several sources, and used primary data with experts. The cases selected are outliers, as we have explained in our methodology section, a characteristic that can bring both benefits and shortcomings to the research. In any case, this study contributes to shed some light over the subject matter - diasporic internationalization - and we hope it is an invitation for other researchers to explore this issue. Finally, there is a dearth of studies on the entrepreneurial activities of the Brazilian diaspora, therefore deserving further research.

\section{References}

Aharoni, Y. (2011). Fifty years of case research in international business: the power of outliers and black swans. In R. Piekkari \& C. Welch (Eds.), Rethinking the case study in international business and management research (pp. 41-54). Cheltenham, UK: Edward Elgar.

Álvarez, S. M. S. (2015). Migrant transnational entrepreneurship in Colombia. In W. Newburry \& M. A. Gonzalez-Perez (Eds.), International business in Latin America: innovation, geography and internationalization (pp. 83-100). London: Palgrave Macmillan.

Assunção, M. R. (2005). Capoeira: the history of an Afro-Brazilian martial art. London, New York: Routledge.

Blazejewski, S. (2011). When truth is the daughter of time: longitudinal case studies in international business research. In R. Piekkari \& C. Welch (Eds.), Rethinking the case study in international business and management research (pp. 251-276). Cheltenham, UK: Edward Elgar.

Bruneau, M. (2010). Diasporas, transnational spaces and communities. In R. Bauböck \& T. Faist (Eds.), Diaspora and transnationalism: concepts, theories and methods (pp. 35-50). Amsterdam: Amsterdam University Press.

Bonaccorsi, A. (1992). On the relationship between firm size and export intensity. Journal of International Business Studies, 23(4), 605-635. doi:10.1057/palgrave.jibs.8490280

Butler, K. D. (2001). Defining diaspora, refining a discourse. Diaspora, 10(2), 189-219. doi: $10.1353 / \mathrm{dsp} .2011 .0014$

Cannon, E. F. (2012). Natural bad boys: the rise of mixed martial arts and the new class of combat sport. In M. K. Booker (Ed.), Blue-collar pop culture: from Nascar to Jersey Shore (Vol. 1, pp. 325380). Santa Barbara, CA: ABC-CLIO. 
Dana, L. P., \& Wright, R. W. (2004). Emerging paradigms of international entrepreneurship. In L. P. Dana (Ed.), Handbook of research on international entrepreneurship (pp. 3-15). Cheltenham, UK: Edward Elgar.

Delamont, S., \& Stephens, N. (2008). Up on the roof: the embodied habitus of diasporic capoeira. Cultural Sociology, 2(1), 57-74. doi: 10.1177/1749975507086274

Faist, T. (2010). Diaspora and transnationalism: what kind of dance partners? In R. Bauböck \& T. Faist (Eds.), Diaspora and transnationalism: concepts, theories and methods (pp. 9-34). Amsterdam: Amsterdam University Press.

Falcão, J. L. C. (2008). A internacionalização da capoeira. Revista Textos do Brasil, 14, 123-133. Retrieved from http://dc.itamaraty.gov.br/publicacoes/textos/portugues/revista14.pdf/view

Frigério, A. (1989). Capoeira: de arte negra a esporte branco. Revista Brasileira de Ciências Sociais, 4(10). Retrieved from http://www.anpocs.org.br/portal/publicacoes/rbcs_00_10/rbcs10_05

Ghauri, P. (2004). Designing and conducting case studies in international business research. In R. Marschan-Piekkari \& C. Welch (Eds.), Handbook of qualitative research methods in international business (pp. 109-124). Cheltenham, UK: Edward Elgar.

Green, T. A., \& Svinth, J. R. (2010). Martial arts of the world: an encyclopedia of history an innovation (Vol. 2). Santa Barbara, CA: Greenwood Publishing Co.

Griffith, L. M. (2013). Apprenticeship pilgrims and the acquisition of legitimacy. Journal of Sport \& Tourism, 18(1), 1-15. doi: 10.1080/14775085.2013.766527

Hedegard, D. (2012). Becoming a capoeirista: a situational approach to interpreting a foreign cultural good. Sociological Inquiry, 82(4), 510-531. doi: 10.1111/j.1475-682X.2012.00415.x

Hintu, S., Forsman, M., \& Kock, S. (2004). A network perspective of international entrepreneurship. In L. P. Dana (Ed.), Handbook of research on international entrepreneurship ( $\mathrm{pp}$ 715-731). Cheltenham, UK: Edward Elgar.

International Brazilian Jiu-Jitsu Federation. (2015). 2015 registered. Retrieved from http://ibjjf.org/registered/

Johanson, J., \& Vahlne, J. E. (2009). The Uppsala internationalization process model revisited: from liability of foreignness to liability of outsidership. Journal of International Business Studies, 40(9), 1411-1431. doi: 10.1057/jibs.2009.24

Joseph, J. (2008). 'Going to Brazil': transnational and corporeal movements of a Canadian-Brazilian martial arts community. Global Networks, 8(2), 194-213. doi: 10.1111/j.1471-0374.2008.00191.x

Kenney, M., Breznitz, D., \& Murphree, M. (2013). Coming back home after the sun rises: returnee entrepreneurs and growth of high tech industries. Research Policy, 42(2), 391-407. doi: 10.1016/j.respol.2012.08.001

Kissau, K., \& Hunger, U. (2010). The internet as a means of studying transnationalism and diaspora. In R. Bauböck \& T. Faist (Eds.), Diaspora and transnationalism: concepts, theories and methods (pp. 245-265). Amsterdam: Amsterdam University Press.

Lesser, J. (1999). Immigrants, minorities, and the struggle for ethnicity in Brazil. Durham, NC: Duke University Press.

Lin, X. (2010). Contemporary diasporic entrepreneurship: a conceptual and comparative framework. In B. Honig, I. Drori, \& B. A. Carmichael (Eds.), Transnational and immigrant entrepreneurship in a globalized world (pp. 31-60). Toronto, Canada: University of Toronto Press. 
Lussac, R. M. P., \& Tubino, M. J. G. (2009). Capoeira: a história e trajetória de um patrimônio cultural do Brasil. Revista da Educação Física/UEM, 20(1), 7-16. doi: 10.4025/reveducfis.v20i1.5815

Matta, J. R., Dib, L. A., \& Mello, R. C. (2013, setembro). O modelo de Uppsala e as redes: uma análise empírica da internacionalização de academias brasileiras de jiu-jitsu. Anais do Congresso Internacional de Administração 2013, Ponta Grossa, PR, Brasil.

Ministério das Relações Exteriores. (2013). Perfil da diáspora brasileira: estimativas. Retrieved January 19, 2015, from http://www.brasileirosnomundo.itamaraty.gov.br/acomunidade/estimativas-populacionais-das-comunidades/estimativas-populacionais-dascomunidades-brasileiras-no-mundo-2013/estimativas-2013-site.jpg

Nakane, C. (1970). Japanese society. Berkeley, CA: University of California Press.

Nanda, R., \& Khanna, T. (2010). Diasporas and domestic entrepreneurs: evidence from the Indian software industry. Journal of Economics \& Management Strategy, 19(4), 991-1012. doi: 10.1111/j.1530-9134.2010.00275.x

Nelson, C. A. (2013). Services marketing in mixed martial arts: developing jiu-jitsu in Seoul, Korea. Journal of Marketing and Management, 4(1), 31-44.

Nkongolo-Bakenda, J. M., \& Chrysostome, E. V. (2013). Engaging diasporas as international entrepreneurs in developing countries: in search of determinants. Journal of International Entrepreneurship, 11(1), 30-64. doi: 10.1007/s10843-012-0098-1

Padilla, B. (2011). Engagement policies and practices: expanding the citizenship of Brazilian diaspora. International Migration, 49(3), 10-29. doi: 10.1111/j.1468-2435.2011.00694.x

Pauwels, P., \& Matthyssens, P. (2004). The architecture of multiple case study research in international business In R. Marschan-Piekkari \& C. Welch (Eds.), Handbook of qualitative research methods in international business (pp. 125-143). Cheltenham, UK: Edward Elgar.

Pries, L. (2004). Transnationalism and migration: new challenges for the social sciences and education. In S. Luchtenberg (Ed.), Migration, education and change (pp. 15-39). London: Routledge.

Rosenfeld, M. (2012). Mobility and social capital among Lebanese and Beninese entrepreneurs engaged in international trade. International Review of Sociology, 22(2), 211-228. doi: $10.1080 / 03906701.2012 .696962$

Saxenian, A. L. (2002). Silicon Valley's new immigrant high growth entrepreneurs. Economic Development Quarterly, 16(1), 20-31. doi: 10.1177/0891242402016001003

Thompson-Chvaicer, M. (2008). The hidden history of capoeira: a collision of cultures in the Brazilian battle dance. Austin, Texas: The University of Texas Press.

Tung, R. L., \& Chung, H. F. L. (2010). Diaspora and trade facilitation: the case of ethnic Chinese in Australia. Asia Pacific Journal of Management, 27(3), 371-392. doi: 10.1007/s10490-009-9146-3

Vieira, L. R., \& Assunção, M. R. (1998). Mitos, controvérsias e fatos: construindo a história da capoeira. Retrieved from http://www.quilombodospalmares.com.br/artigos/Mitos, $\% 20$ controv\%E9rsias\%20e\%20fatos\%2 0da\%20capoeira.doc

Walder, M. (2008). Brazilian jiu-jitsu. London: New Holland.

Wong, L. L., \& Ng, M. (2002). The emergence of small transnational enterprise in Vancouver: the case of Chinese entrepreneur immigrants. International Journal of Urban and Regional Research, 26(3), 508-530. doi: 10.1111/1468-2427.00396 
Wulfhorst, C., \& Vianna, E. (2012). Communicating new forms of belonging in the transnational space of capoeira. In D. Cogo, M. El Haiji, \& A. Huertas (Eds.), Diásporas, migraciones, tecnologías de la comunicación e identidades transnacionales (pp. 85-104). Barcelona, Espanha: Institut de la Comunicació, Universitat Autónoma de Barcelona.

Yeung, H. W.-C. (2004). International entrepreneurship and Chinese business research. In L. P. Dana (Ed.), Handbook of research on international entrepreneurship (pp. 73-93). Cheltenham, UK: Edward Elgar.

\section{Authors' Profiles}

Angela da Rocha

IAG Business School, Rua Marques de São Vicente, 225, 22451-041, Rio de Janeiro, RJ, Brazil. E-mail address: angelarocha@iag.puc-rio.br

Felipe Esteves

IAG Business School, Rua Marques de São Vicente, 225, 22451-041, Rio de Janeiro, RJ, Brazil. E-mail address: esteves.lipe@gmail.com

Renato Cotta de Mello

Rua Pascoal Lemme, 355, 21941-616, Rio de Janeiro, RJ, Brazil. E-mail address: renato@ coppead.ufrj.br

Jorge Ferreira da Silva

IAG Business School, Rua Marques de São Vicente, 225, 22451-041, Rio de Janeiro, RJ, Brazil. E-mail address: shopshop@iag.puc-rio.br 